\title{
Municipal Solid Waste Management: A comparative study between Sydney (Australia) and Pune (India)
}

\author{
Daniella Sohkhlet ${ }^{1 *}$, and Shekhar Nagargoje ${ }^{2}$ \\ ${ }^{1}$ RICS School of Built Environment, Amity University, Mumbai, India \\ ${ }^{2}$ RICS School of Built Environment, Amity University, Mumbai, India
}

\begin{abstract}
As rapid urbanization continues to take place, with a projected $68 \%$ of the world's population expected to live in cities by 2050 according to the UN, waste management in proximity to human settlements poses problematic. Although waste generation and failure of its management is seen as a huge problem in developing cities, wealthier cities generate more waste than less affluent cities, and thus waste management is a crucial issue in developed as well as developing cities for obvious ecological reasons and for sustainability. However, while collection of waste by high GDP cities is more frequent than collection in low GDP cities, it does not imply that the issue of waste management has been resolved. A significant portion of the world still dumps its waste in landfills. Furthermore, it is projected that by 2025 , lower middle-income groups will produce the most amounts of waste, while high-income groups are expected to generate the second largest amount of waste. Accordingly, it is important to understand methods of collection and disposal of solid waste carried out by cites varying in GDP and HDI to combat the issue of waste management through landfills for the purpose of creating a sustainable future. This paper is a study of existing waste management methods implemented by the governing bodies of selected cities and progress towards future policies that these governing bodies have laid out. Comparisons of existing problems faced by each city, collection methods and coverage, recycle coverage and rates, unique waste management approaches, and plans to tackle waste are carried out. The analysis can thus serve as a reference for emerging cities lacking resources that can adapt strategies described, as well as for established cities that can easily adopt certain measures to safeguard their respective ecologies and take steps towards sustainability.
\end{abstract}

\section{Introduction}

Solid Waste Management within the framework of the city is a core element of its infrastructure. As the urban centre takes its place on the international stage, more sophisticated management methods in solid waste management is required to relieve the stresses of increasing relocation of the world's population to cities. Additionally, it is required for the smooth operations of social economic activities. However, this is not the only reason we must devote our efforts to understanding solid waste management practices. The environment bears the cost of poor practices. The world generated 1.6 billion tonnes of carbon dioxide equivalent greenhouse gas emissions from solid waste management in 2016, making up $5 \%$ of global emissions [1]. If renewable energy is to increase its foothold, waste management and resource recovery can not only generate large amounts of income and employment but can also spur the shift to clean energy. However, current solid waste management practices are poor and observed to be detrimental to the micro-level as well as macro-level functioning of the world's communities and the planet's ecosystem. Solid waste that has not been collected ends up in drains, clogging drainage systems and creating unsanitary conditions and breeding grounds for diseases. Burning of solid waste also adversely impacts the air as well as human health. Moreover, at least 2 billion people do not have access to regular waste collection, and only $5 \%$ of waste in squatter areas is collected [2]. When waste is collected, it is often the case that waste is openly dumped or dumped in landfills that are unmonitored and uncontrolled. Globally, $37 \%$ of waste is discarded in landfills, $8 \%$ of which are sanitary landfills with gas collection systems [1]. Another 33\% of waste is disposed through open dumping and $11 \%$ is incinerated. Only $19 \%$ of the world's waste is recovered through recycling and composting [1].

Unsurprisingly, most low-income countries rely on open dumping while high-income and upper-middleincome countries have access to controlled landfills and other waste management infrastructure. However, landfills continue to be the most used form of waste disposal. $54 \%$ of landfill disposal is done by uppermiddle-income countries [1].

For this reason, Sydney Australia and India on the basis of their differences are compared. Australia has a GDP per capita of 43,560 USD and HDI of 0.939 , while India has a GDP per capita of 6,353 USD and HDI value of 0.640 [3].

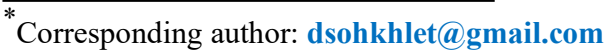




\section{Factors of Comparison}

\subsection{Gross Domestic Product (GDP)}

GDP values taken into consideration in this paper are taken from UNDP 2018 statistical updates and are expressed as the sum of all incomes of a country's residents and businesses including taxes in a particular period. To understand GDP per capita, the GDP is divided by the total population in the same period. The values are expressed in international dollars using purchasing power parity (PPP) rates. [3]

\subsection{Human Development Index (HDI)}

The index accounts for three dimensions of development. The first dimension is measured by life expectancy at birth, while access to knowledge is measured by mean years of schooling and expected years of schooling, whereas a decent standard of living is measured by gross national income per capita. [3]

\subsection{Municipal Solid Waste (MSW)}

MSW is waste that consists of non-hazardous trash generated from "households, commercial and business establishments, industrial and agricultural premises, institutions such as schools and hospitals, public spaces such as parks and streets and construction sites" [2]. Municipal solid waste is further divided into regularly collected and uncollected municipal solid waste, where the former is collected by municipal authorities or licensed private contractors on a routine schedule and the latter remains scattered through the city due to a lack of collection services, particularly seen in informal settlements areas. This paper will be examining only regularly collected waste.

\subsection{Waste Classification and Composition}

Study of waste generation sources and composition and classification of waste by respective local municipal authorities. With Sydney, it is the City of Sydney and Pune is governed by Pune Municipal Corporation.

\subsection{Waste Trends}

Past and projected trends in waste generation as well as their sources.

\subsection{Waste Collection}

Defining comparison between the two cities and how their local governments differ in how they charge fees for waste management, how they collect and segregate waste, how often they collect the waste and the extent of the coverage.

\subsection{Waste Disposal}

Examination of current waste infrastructure in how waste is disposed/processed.

\subsection{Successes and Strategies}

Achievements and policies used in solid waste management as well as strategies for the future

\subsection{Challenges and Opportunities}

Existing challenges and whether these challenges can be turned into opportunities.

\section{Sydney}

Sydney covers $26.15 \mathrm{sqm}$ of area and has a population of 210,000 with a transient population of 1.2 million per day, which includes workers, residents, visitors, and students [4]. The city is projected to grow by 70,000 residents and 120,000 workers by 2031 . Sydney represents $22 \%$ and $7 \%$ of the NSW and national GDP respectively. [5]

The City of Sydney Council is made up of 10 village precincts and governs 33 suburbs and 23 localities. The council is responsible for the collection of waste and recycling in compliance with the Local Government Act 1993. The Environment Committee of the City of Sydney Council in particular oversees environmental issues within the government area. The City works in conjunction with and complies with regulations of the NSW state government. [6].

\subsection{Waste Classification and Composition}

While the City of Sydney (C.o.S) has categorized waste into three categories, explicitly, Residential and Public Space waste, Commercial and Industrial waste, and Construction and Demolition waste, the City only collects Domestic waste which it defines as "all waste generated by the ordinary use of residential premises and collected by the City or its agents". [7] Businesses are responsible for collecting their own waste, typically carried out by engaging a commercial waste contractor who operate under the Waste Contractors and Recyclers Association of NSW (WCRA) Code of Practice. The WCRA Code of Practice is subject to the Waste Policy in case of a conflict. [7]

Residential and Public Spaces waste contribute up to $4 \%$ of Sydney's total landfill waste. Waste generated by businesses consists of largely organic or biodegradable waste and is a major contributor to landfill waste. C\&D waste generates more than 1.2 million tonnes per year out of which 400,000 tonnes are generated directly or indirectly through maintenance or contracts. [4]

While the New South Wales Environment Protection Authority (NSW EPA) guidelines of waste classification categorize solid waste into putrescible and non-putrescible, the C.o.S limits its scope to domestic waste from single dwelling or houses and multi-unit dwellings or apartments in the area of its jurisdiction. In general, NSW EPA describes putrescible solid waste as 
household waste, waste from litter bins, manure and night soil, disposable nappies, incontinence pads or sanitary napkins, food waste, animal waste (including dead animals and mixtures of animal parts), grit or screenings from sewage treatment systems without free liquids, and mixtures of the above. Non-putrescible wastes range from glass, plastic, rubber, plasterboard, ceramics, bricks, concrete, metal, paper or cardboard, to building and demolition waste and other inorganic material. According to Sydney's 2017 Waste Policy, domestic waste collected is largely made up of:

\subsubsection{Garbage}

Garbage includes food waste, nappies, meat trays, foam packaging, plastic wrappers and crockery.

\subsubsection{Recycling}

The City collects recyclables which includes paper, cardboard, aerosol cans, metal cans \& tins, glass containers, plastic containers.

\subsubsection{Garden Organics}

The City collects grass clippings, flowers and weeds, leaves, tree and shrub prunings, sticks and branches. Building materials, rocks and soil, tree stumps and big branches are not collected.

\subsubsection{Bulky Household Waste}

Made up of furniture, mattresses, whitegoods or excess green waste.

\subsubsection{Building and Renovation Waste}

Includes asbestos, rubble, soil, timber, fencing, wooden pallets.

\subsubsection{Hazardous Household Items}

The City provides other methods for storage of hazardous household items (flammable liquids, gas bottles, oil, poisons or other chemicals, paints \& solvents, batteries, energy-saving/fluorescent light globes, e-waste, clinical waste).

Table 1. Domestic Waste Content in Sydney. Source: City of Sydney Interim Waste Strategy, 2011

\begin{tabular}{|l|l|}
\hline \multicolumn{2}{|c|}{ Domestic Waste Content } \\
\hline Renovation Waste & $4 \%$ \\
\hline Hazardous & $2 \%$ \\
\hline Textile & $3 \%$ \\
\hline Glass & $9 \%$ \\
\hline Metal & $2 \%$ \\
\hline Plastics & $12 \%$ \\
\hline Other & $7 \%$ \\
\hline
\end{tabular}

\begin{tabular}{|l|l|}
\hline Food & $37 \%$ \\
\hline Greenwaste & $2 \%$ \\
\hline Paper and Cardboard & $21 \%$ \\
\hline
\end{tabular}

Table 2. Commercial + Industrial Waste Content. Source: City of Sydney Interim Waste Strategy 2011

\begin{tabular}{|l|l|}
\hline \multicolumn{2}{|c|}{ Commercial + Industrial Waste Content } \\
\hline C\&D material & $8 \%$ \\
\hline E-Waste & $1 \%$ \\
\hline Hazardous & $14 \%$ \\
\hline Textile & $4 \%$ \\
\hline Glass & $2 \%$ \\
\hline Metal & $2 \%$ \\
\hline Plastics & $12 \%$ \\
\hline Wood & $13 \%$ \\
\hline Other & $13 \%$ \\
\hline Food & $14 \%$ \\
\hline Greenwaste & $3 \%$ \\
\hline Paper and Cardboard & $14 \%$ \\
\hline
\end{tabular}

\subsection{Waste Trends}

More than 5,500 tonnes of waste are produced by the metropolitan city every day amounting to 65,000 tonnes of domestic waste each year from more than 115,000 households contributing to $8 \%$ of the city's total greenhouse gas emissions. However, in $2016-17$, carbon emissions decreased by $7 \%$ due to waste diversion and advanced waste treatment practices.

Table 3. Waste Generated vs. 2030 forecast

\begin{tabular}{|c|c|c|c|c|}
\hline $\begin{array}{c}\text { Type of } \\
\text { waste }\end{array}$ & $\begin{array}{c}\text { Tonnes } \\
\text { per year }\end{array}$ & $\begin{array}{c}\text { KG per } \\
\text { person } \\
\text { per day }\end{array}$ & $\begin{array}{c}\text { Of } \\
\text { Total } \\
\text { Waste }\end{array}$ & $\begin{array}{c}\mathbf{2 0 3 0} \\
\text { forecast } \\
\text { (tonnes) }\end{array}$ \\
\hline Households & 65,000 & 1 & $19 \%$ & 102,000 \\
\hline $\begin{array}{c}\text { Public } \\
\text { Places }\end{array}$ & 11,000 & 2 & $52 \%$ & 800,000 \\
\hline $\begin{array}{c}\text { Commercial } \\
\text { \& Industrial }\end{array}$ & 700,000 & 4 & $29 \%$ & $1,500,00$ \\
\hline $\begin{array}{c}\text { Constructio } \\
\text { n \& } \\
\text { Demolition }\end{array}$ & $1,300,000$ & \multicolumn{2}{|c|}{} \\
\hline
\end{tabular}

Table 4. Waste Diverted from Landfills

\begin{tabular}{|c|c|c|}
\hline Source & $\begin{array}{c}\text { Tonnes } \\
\text { generated }\end{array}$ & $\begin{array}{c}\text { Diverted from } \\
\text { landfills }\end{array}$ \\
\hline Buildings & 400 & $35 \%$ \\
\hline Construction works & 4000 & $90 \%$ \\
\hline Public spaces & 11,000 & $18 \%$ \\
\hline
\end{tabular}

While $69 \%$ of domestic waste is recycled, 2000 tonnes and above each day goes to landfill without further means to re-use, recycle or recover for energy. [4] 


\subsection{Waste Collection}

\subsubsection{Charges}

Residents are charged annually for provision of waste management services which account for administration, collection, processing, treatment, community education, and other activities associated with domestic waste services. The domestic waste charge is calculated on the size of garbage bin, amount of waste generated, and frequency of collection. A standard charge applies for single-dwellings based on the size of waste bin and collection frequency. For multi-unit dwellings, the charge is based on the number of units sharing the service, frequency of collections, size of the bins, and whether the waste is compacted. Schools within the local government area are provided recycling collection services free of cost up to a maximum of four 240 litre recycling bins per week. [7]

\subsubsection{Segregation and Storage}

Containers are provided ranging from $55 \mathrm{~L}$ carry bins to mobile bins and bulk capacity skip bins, which the City defines as, "a container designed and used for the storage, transport and disposal of waste" [7]. While garbage and recyclables are disposed in colour coded bins, garden organics must be bundled, boxed or bagged and then placed into green lid bins. If garden organics are too big to fit in the provided bins, bookings can be made for collection. Bulky household waste is collected by calling the City's Customer Service Centre or can independently be taken to a commercial waste facility to dispose of for a fee. The City instructs disposal of whitegoods to be placed separately to other items where they collect no more than one cubic metre of waste. Building and renovation waste such as asbestos, rubble, soil, timber, fencing, or wooden pallets must be disposed of at the appropriate waste facility or by hiring a waste contractor for collection who often provide residents with a skip bin which is subsequently collected. Hazardous household items and e-waste can be independently disposed of by calling the City's Customer Service Centre for details of disposal locations.

Table 5. Storage Methods in Sydney

\begin{tabular}{|c|c|c|}
\hline $\begin{array}{c}\text { Waste } \\
\text { Type }\end{array}$ & Disposal Method & $\begin{array}{c}\text { Standard } \\
\text { Size }\end{array}$ \\
\hline Garbage & Red lid bins & $120 \mathrm{~L}$ \\
\hline Recycling & Yellow lid bins & $120 \mathrm{~L}$ \\
\hline $\begin{array}{c}\text { Garden } \\
\text { Organics }\end{array}$ & Green lid bins & $240 \mathrm{~L}$ \\
\hline
\end{tabular}

\subsubsection{Frequency and Mode of Collection}

Garbage and recyclable waste is collected once a week from single dwellings. Multi-unit dwellings or apartments without communal bins receive same collection as houses and have a variety of frequencies. While the City provides collection only for domestic waste, it has allotted time zones for commercial collection for waste contractors as well. 45 vehicles which include rear-lift compaction trucks for picking up domestic waste and recycling are maintained or contracted by the C.o.S. [7]

Table 6. Frequency of Collection in Sydney

\begin{tabular}{|c|c|}
\hline Waste Type & Frequency \\
\hline Garbage & Weekly \\
\hline Recycling & Weekly \\
\hline Garden Organics & Fortnightly / Booking \\
\hline $\begin{array}{c}\text { White goods \& Bulky } \\
\text { Household items }\end{array}$ & $\begin{array}{c}\text { Weekly through } \\
\text { booking }\end{array}$ \\
\hline $\begin{array}{c}\text { E-Waste \& Hazardous } \\
\text { waste }\end{array}$ & Drop-off events \\
\hline
\end{tabular}

Table 7. Domestic Waste Collection Time Zones in Sydney

\begin{tabular}{|l|c|c|}
\hline \multicolumn{1}{|c|}{ Zones } & Time & Days \\
\hline $\begin{array}{l}\text { Main and } \\
\text { Arterial Roads } \\
\text { Zone }\end{array}$ & $5: 30 \mathrm{AM}-10 \mathrm{PM}$ & Every day \\
\hline $\begin{array}{l}\text { Residential } \\
\text { Roads Zone }\end{array}$ & $6: 00 \mathrm{AM}-10 \mathrm{PM}$ & Mon - Sat \\
\cline { 2 - 3 } $\begin{array}{l}\text { CBD Light } \\
\text { Rail } \\
\begin{array}{l}\text { Collection } \\
\text { Zone }\end{array}\end{array}$ & $\begin{array}{c}1: 00 \mathrm{AM}-10 \mathrm{PM} \\
\mathrm{AM}\end{array}$ & Sundays \\
\hline
\end{tabular}

\subsubsection{Collection Coverage}

The C.o.S covers its residential suburbs, commercial and CBD districts based on frequency, where commercial and domestic waste are collected individually and separately. Each category of waste has allotted routes classified by zones (main and arterial roads, residential roads, CBD light rail, and limited collection time zones for all other streets, etc.) with set routines and time slots that are made known to the public.

\subsection{Waste Disposal}

Australia's waste is managed by a combination of public, private and public-private players. The country's waste and resource recovery sector contribute $0.43 \%$ for the national GDP. Collection operations, landfilling, and operating waste infrastructure are also carried out by private players, who mostly operate in larger urban centres. (Fig 1). One of the large operators include Veolia, operating $250 \mathrm{~km}$. away from Sydney. While smaller operators deal in focused activities such as composting, skip bin operation or operate regionally. [8]

While transfer stations, container systems, material recovery facilities and composting facilities are found to be operated by a combination of local governments and private entities who are contracted by local governments or private businesses, alternative waste treatment facilities (AWT), landfills and processing facilities for C\&D and 


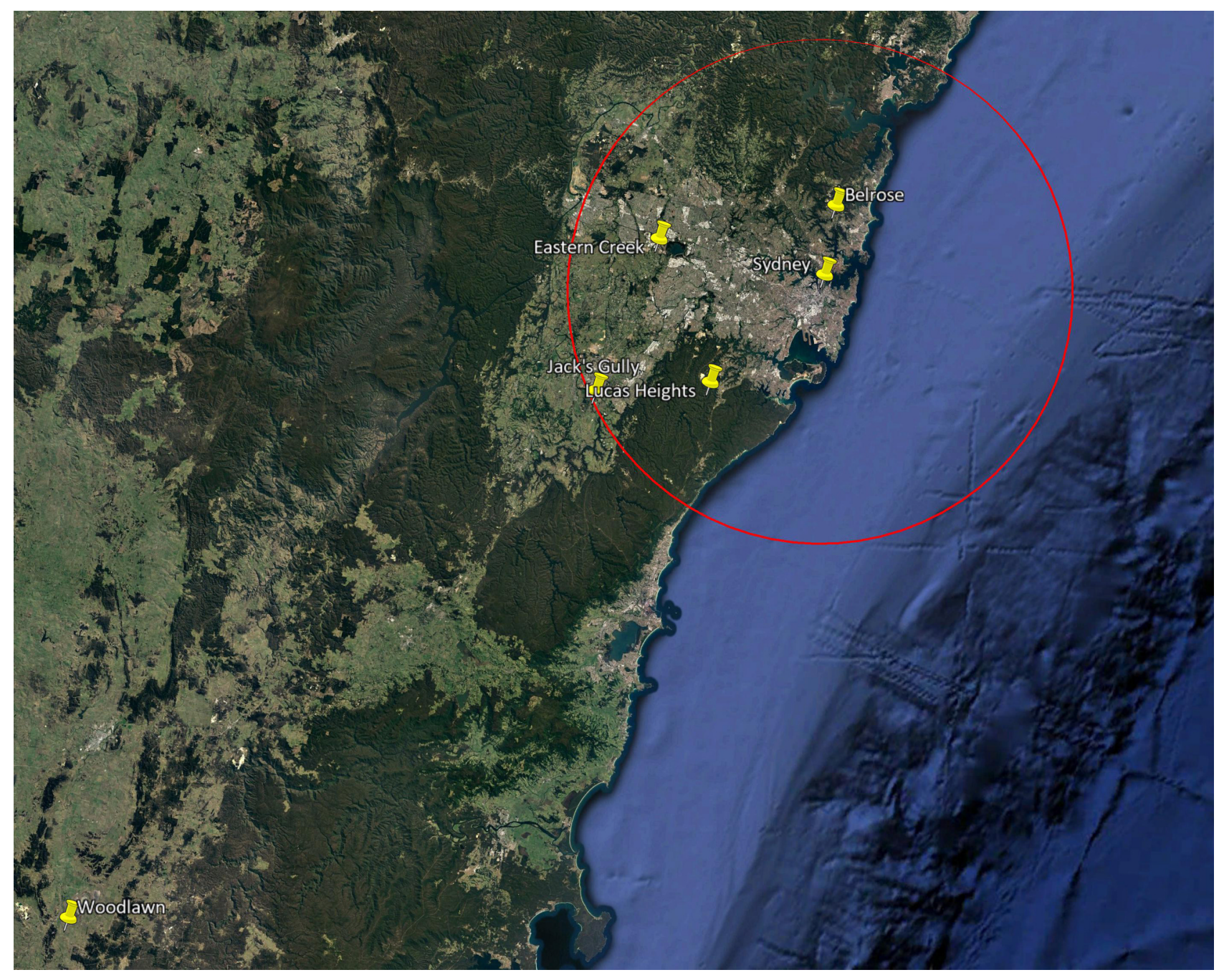

Fig 1. Location of landfills closest to Sydney Area (a $50 \mathrm{~km}$ radius) Source: Google Earth Pro, 2020

C\&I are exclusively run by private businesses, with the exception of landfills in rural areas being run by local governments. [8]

Landfill sites in the area are located away from the point of waste generation due to competing land priorities as seen in Fig. 4, which shows the location of some of the primary landfill sites used by Sydney and their proximity to the urban centre. These are Jack's Gully, Genesis Facility at Eastern Creek, Lucas Heights, and Belrose. In addition to these, the Woodlawn landfill at Tarago, operated by Veolia, $250 \mathrm{~km}$. south-west of Sydney receives the largest amount of waste in Australia, more than 400,000 tonnes per year [9]. Waste from Sydney to Woodlawn is transported by rail.

In 2010, approved capacity of putrescible landfills was 40 MT and 4.7 MT in inert landfills. However, by 2022, Sydney's landfills would have to be replaced [9].

Current disposal pathways place recycling as the second stage of waste recovery and disposal. Recycling of garden organics, e-waste, household and whitegoods, and by-products of alternative waste treatment is carried out after collection. The third stage is treatment of only two types of waste - mixed waste and household hazard waste. The remaining get sent to landfill sites [10].
Out of the 65,000 tonnes and 11,000 tonnes of waste generated in 2016 by the city of Sydney area's residential and public spaces, $31 \%$ and $82 \%$ respectively goes to landfills and 69\% is diverted [4]. Comparatively, in 2012, the City diverted $66 \%$ of 62,598 tonnes of collected municipal waste from landfills [10].

Although $69 \%$ of residential waste is presently diverted from landfills by reprocessing recyclables and composting food and garden waste, a large percentage of landfill waste is made up of other waste, particularly C\&D waste. Recyclables also tend to enter landfills due to waste segregation from the source not being effectively managed. From a broader scale, 13.8 MT of MSW was generated nationally in 2016 - 17; 21.7 MT (40\% of core waste generated) of Australia's waste was deposited in landfill in the year 2016-17 [8], and almost all of the 140,000 tonnes of e-waste generated annually in Australia is sent to landfill.

\subsection{Successes and Strategies}

Although Sydney is one of the highest waste generating councils in Australia, it accounts for only 20\% of domestic waste being sent to landfill [11]. Waste targets have been maintained and achieved, with the $66 \%$ 
domestic waste diversion from landfill target rate being crossed in 2012. Recycling rates for public waste increased from $26 \%$ to $46 \%$, while $100 \%$ of C\&D waste was diverted for the year 2018-19, Several community and city-wide recycling, composting, upgradations and awareness initiatives have been increasing with guidance and support from C.o.S that foster innovation and improvement amongst local businesses, communities and residents, with a focus on the development of a circular economy approach. This includes an increase in recycling services, a 24/7 cleaning and waste response team, and consistent provision of advice to local businesses. These trends are only expected to grow as laid out in the council's as well as the state's strategic policies and master plans. [4, 5, 12].

NSW imposed a 'waste levy' in 2014 that charged EPA-licensed landfill operators in NSW and the Sydney metropolitan area for each tonne of waste being sent to the

landfill facility. The levy is an attempt to discourage landfill disposal and aid recycling and resource recovery. Together with the NSW government, initiatives such as Waste Less Recycle More (WLRM) funded by the waste levy has assisted in the development and upgradation of waste infrastructure and community recycling centres. [5, $13,14]$.

The C.o.S as an independent entity has identified environmental sustainability targets in terms of waste management with a zero-waste target through various policies, benchmarks and guidelines as listed below.

Table 8. Policies and Guidelines in SWM by City of Sydney

\begin{tabular}{|c|c|c|c|}
\hline Title & $\begin{array}{l}\text { Time- } \\
\text { frame }\end{array}$ & Type & Details \\
\hline $\begin{array}{l}\text { Environmen } \\
\text { tal Action }\end{array}$ & $\begin{array}{c}2016- \\
2021\end{array}$ & $\begin{array}{l}\text { Strategy } \\
\text { and } \\
\text { Action } \\
\text { Plan }\end{array}$ & $\begin{array}{l}\text { Set benchmarks higher } \\
\text { than compliance } \\
\text { requirements in six areas: } \\
\text { low carbon, water } \\
\text { sensitivity, climate } \\
\text { resilient, zero waste, active } \\
\text { and connected, green and } \\
\text { cool. }\end{array}$ \\
\hline $\begin{array}{l}\text { Leave } \\
\text { Nothing to } \\
\text { Waste } \\
\text { Strategy and } \\
\text { Action Plan }\end{array}$ & $\begin{array}{c}2017- \\
2030\end{array}$ & Plan & $\begin{array}{l}\text { Waste avoidance, reuse } \\
\text { and better recycling }\end{array}$ \\
\hline $\begin{array}{l}\text { Sustainable } \\
\text { Sydney }\end{array}$ & 2030 & $\begin{array}{l}\text { Commu } \\
\text { nity } \\
\text { Strategic } \\
\text { Plan }\end{array}$ & $\begin{array}{l}\text { As a commitment to the } \\
\text { Sustainable Development } \\
\text { Goals (12 SDGs). }\end{array}$ \\
\hline $\begin{array}{l}\text { Advanced } \\
\text { Waste } \\
\text { Treatment } \\
\text { Plan }\end{array}$ & $\begin{array}{l}2013- \\
2030\end{array}$ & $\begin{array}{l}\text { Master } \\
\text { Plan }\end{array}$ & $\begin{array}{l}\text { Integrating waste and } \\
\text { energy solutions to divert } \\
\text { from landfills and deal } \\
\text { with changing nature of } \\
\text { waste }\end{array}$ \\
\hline $\begin{array}{l}\text { Sustainabilit } \\
\text { y } 2050\end{array}$ & 2050 & Event & $\begin{array}{l}\text { Engaged decision-makers, } \\
\text { advocates, community } \\
\text { leaders }\end{array}$ \\
\hline
\end{tabular}

\begin{tabular}{|c|c|c|c|}
\hline $\begin{array}{l}\text { Green } \\
\text { Environmen } \\
\text { tal } \\
\text { Sustainabilit } \\
\text { y }\end{array}$ & $\begin{array}{c}\text { Bi- } \\
\text { annual }\end{array}$ & $\begin{array}{c}\text { Progress } \\
\text { Report }\end{array}$ & $\begin{array}{l}\text { Benchmarks progress } \\
\text { against sustainability } \\
\text { targets }\end{array}$ \\
\hline
\end{tabular}

The City has identified Alternative Waste Treatment (AWT) as a solution to minimize waste being sent to landfill. C.o.S has reportedly ensured that domestic waste is not directly being sent to landfills due to initial processing at AWT facilities. In this effort, the City has upgraded 1,670 residential apartment building bin rooms to improve recycling and waste management. [10]

The model of contracting of private businesses and privatization of waste infrastructure has allowed for the creation of jobs and a requirement of higher-level expertise, and GDP growth. The waste and resource recovery sector provides a stable source of income within the commercial sector.

\subsection{Challenges and Opportunities}

Although the C.o.S has several targets and multiple action plans and strategies to move towards a zero-waste city, the divergence of local councils and state government has led to gaps in data and reporting. Limited information regarding waste processing plants and the amount of waste being processed is found because these operations are run by private entities, whether small or large. This creates obstacles in transparency that would be required to effectively manage waste. However, the national government has attempted to harmonize regulation by developing a National Waste Policy which has included efforts in reporting on the state of waste management of the country.

Due to the fact that operation costs of landfills are comparatively lower than waste recycling systems and due to their usually close proximity to the city, landfills have tended to be the go-to waste management method in NSW. The privatization of landfill ownership and the tradition of landfill use has led private owners to introduce larger and more revenue producing landfills [15]. 3\% of Sydney's total greenhouse gas emission is contributed by landfill methane emission while other greenhouse gas emissions from landfill equate to 25,510 tons of carbon dioxide. While the 'zero waste to landfill' target by 2030 is progressing, the average capacity of 300,000 tonnes of Sydney's landfills provide cause for a laid-back approach where half of the waste still arrives in landfills. As the landfills increase in capacity, supplementary land would have to be acquired further away from the city, leading to larger carbon footprints. Additionally, these landfills have created barriers in the growth of the city.

Sydney is home to a steadily increasing population as well as worker and visitor groups. With $75 \%$ of residential units in the city being apartments, waste infrastructure will increasingly be burdened, and more effective management methods will be required.

With progressive complexity in the composition of products over the last few decades, the nature of waste is 
drastically changing. This includes superfluous packaging that is generated within the city. As consumption of products increases, the landfill method would prove to be a method that can be compared to dumping toxic waste into the sea if seen as hindsight by future generations.

A vital opportunity can be found in waste to energy systems that has not been fully implemented as yet, but has been identified by the Advanced Waste Treatment Plan 2013 -2030, which can reduce greenhouse gas emissions by $70 \%$ by 2030 in conjunction with the Renewable Energy and Trigeneration Energy Master Plan. [10]

\section{Pune}

With a population over 5 million in 2011 in the Pune Urban Agglomeration and over 4 million in Pune City, the Indian IT hub has been growing at a rapid rate. Contributing $26.5 \%$ to India's GDP, the city owes its increased standard of living not only to its IT and ITeS sectors, but also to its biotechnology, manufacturing and education sectors. The form of growth it has taken since 2001 has shown to be headed towards decreasing density at an annual rate of $-4.8 \%$. However, while urban sprawl is occurring, the city's overall population is projected to grow to a population of 6 million by $2026.25 \%$ of properties are situated in slums, making up $40 \%$ of Pune's population. Pune is under the jurisdiction of P.M.C who has defined the city to occupy y 244 sq. km. P.M.C manages the city through 4 administrative Zones comprising of three or four Wards which is further subdivided into three to four Prabhags. At the lowest level, Prabhags are made up of Kothis all totalling 152 kothis, 76 prabhags, 14 wards and 4 zones. [16-18]

The management of solid waste in terms of collection, transportation and disposal, including reduction, reuse, recycling and resource recovery is the responsibility of the Pune Municipal Corporation (P.M.C) in compliance with the Bombay Provincial Municipal Act of 1949 and the Government of India Municipal Solid Waste Rules of 2000, among others. Specifically, the Department of Health headed by the Medical Officer of Health (MOH) who is assisted by the Deputy Health Officer of SWM oversees solid waste management for the city of Pune. [16, 18]

\subsection{Waste Classification and Composition}

The P.M.C has extensively detailed the classification of waste in the Public Health \& Sanitation Bye-Laws 2014, listing and describing 25 types of waste. Municipal Solid Waste is defined as waste that consists of "commercial, residential, and other waste generated in (a municipal or notified area) either in solid or semi-solid form excluding industrial hazardous waste, and it also includes treated bio-medical waste" [19].

Classification of municipal solid waste as defined above depends on the source of waste generation, which can be categorized as Residential (individual households, government and private colonies/societies, bungalows, multi storied buildings, apartments, row houses, tenements, townships, slums and chawls), Commercial (ranging from hotels and eateries to flower markets, marriage halls, and construction sites) as well as Educational, Public and Private Gardens, Heritage Buildings, and Religious Places. [19] Composition of typical waste generated is shown in Fig. 2 and 3 below.

\section{MSW Composition}

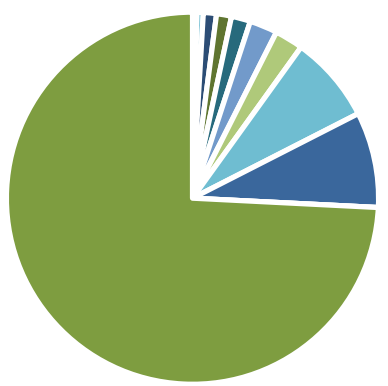

$$
\begin{array}{ll}
\text { - Electronic 0.06\% } & \text { - Metal } 0.33 \% \\
\text { - Shoes } 0.54 \% & \text { - Inert } 1.14 \% \\
\text { - Other } 1.3 \% & \text { - Cloth } 1.66 \% \\
\text { - Sanitary 2.42\% } & \text { - Glass } 2.47 \% \\
\text { - Paper 7.57\% } & \text { - Plastic } 8.31 \% \\
\text { - Organic 74.2\% } &
\end{array}
$$

Fig. 2. Municipal Solid Waste Content in Pune. Source: Pune Municipal Corporation, SWaCH Quarterly Report to P.M.C (Pune, 2018).

MSW by Sources

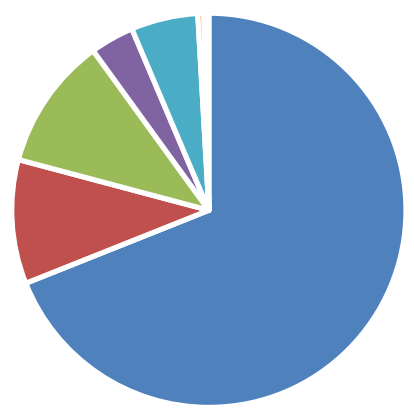

$$
\begin{aligned}
& \text { - Household 69\% } \\
& \text { - Street Sweeping and Drainage Cleaning 10.2\% } \\
& \text { - Hotels \& Restaurants } 10.9 \% \\
& \text { - Markets / Commercial Area 3.6\% } \\
& \text { - C \& D Waste 5.5\% } \\
& \text { - Fruit, vegetable, fish, meat market waste 0.5\% } \\
& \text { - Biomedical 0.4\% }
\end{aligned}
$$

Fig. 3. MSW by Sources in Pune. Source: Integrated Solid Waste Management, P.M.C, 2015 
Accordingly, the 2014 Bye-Laws describe municipal solid waste being made up of the following:

\subsubsection{Bio-degradable Waste / Wet Waste}

Consists of bio-degradable wastes such as tea leaves, eggshells, fruit and vegetable peels, meat and bones, garden and leaf litter, animal litter, soiled paper, house dust, etc.

\subsubsection{Recyclable Waste / Dry Waste}

Consists of paper, metal, plastic \& rubber, glass and any other material which is recyclable in nature.

\subsubsection{Construction and Demolition Waste (C\&D waste)}

Consists of waste generated by construction, refurbishment, repairs and demolition of houses, commercial buildings and other structures.

\subsubsection{E-Waste}

Consists of information technology and telecommunication equipment, consumer electronics, and related waste.

\subsubsection{Commercial/Household Hazardous, Bio- medical \& Sanitary Waste}

Consists of any chemically hazardous components found in household cleaners, automotive products, personal care, and related items.

\subsection{Waste Trends}

Pune generated an average of 1650 MT of solid waste per day in 2016-17, with each person contributing approximately 364 grams each day across economic groups, translating to $0.07 \mathrm{tCO}_{2} \mathrm{e}$ or $4 \%$ of carbon emissions per capita. [20]

\subsection{Waste Collection}

\subsubsection{Charges}

P.M.C has outlined a uniform user fee for door to door collections that was enforced in 2017. Costs incurred for management and equipment procurement and maintenance are maintained by P.M.C. $[16,21]$

\subsubsection{Frequency and Mode of Collection}

Waste is collected by various agents through primary, and secondary means. Municipal Solid Waste is largely collected through a door to door service making up 43\% of the total collection, through the Solid Waste Collection and Handling $(\mathrm{SWaCH})$, a social and civic cooperative involving informal workers. Secondly, accounting for $12 \%$ of primary collection, tipper trucks commonly known as "ghantagadi" translated as "hourly trucks" or "bell ringing vehicles" collect recyclable and nonbiodegradable waste from gates of buildings according to programmed routes through prabhags. Inner city areas that are not accessible to trucks are provided with pushcart services. The waste is then transferred to a station within each ward. Waste from hotels are collected by a specific collection of trucks. $40 \%$ of primary collections are from community bins made by Dumper Placer trucks which also transfer the waste to the transfer station. Waste dumped along streets and roads are also collected by P.M.C to be taken to the stations, making up $5 \%$ of primary collections. [16, 18, 20, 22]

\section{Projected Population and Waste Generation}

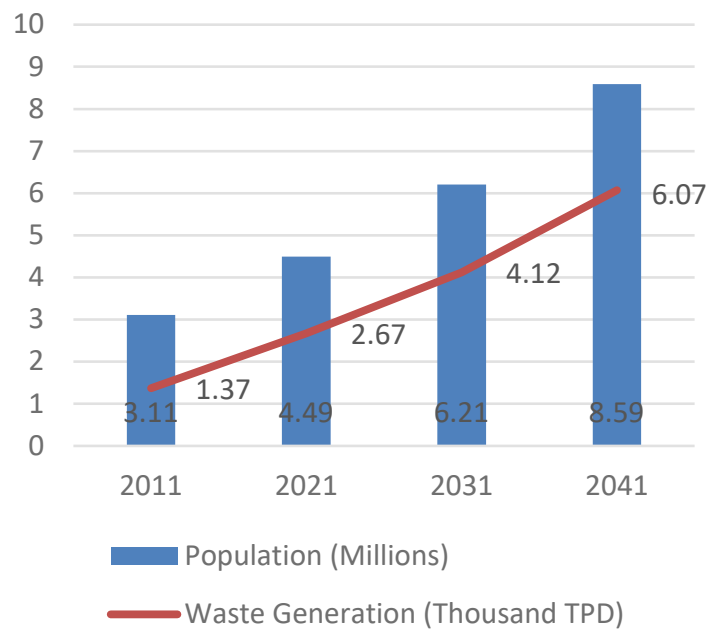

Fig. 4. Segregation of MSW at Source in Pune. Source: Integrated Solid Waste Management, P.M.C, 2015

\section{Segregation at Source \%}

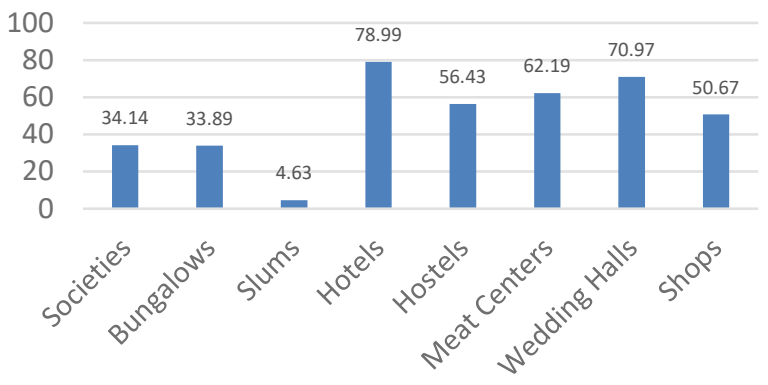

Fig. 5. Segregation of MSW at Source in Pune. Source: Integrated Solid Waste Management, P.M.C, 2015

Bulk Refuse Carriers (BRC) compactors then transport waste from transfer stations to dry or wet waste processing plants, respectively. [18]

C\&D waste is currently being directly disposed in low lying areas along rivers. [23] 
Table 9. Collection Power in Pune

\begin{tabular}{|c|c|c|}
\hline Collection Mode & $\begin{array}{c}\text { Strength in } \\
\text { nos. }\end{array}$ & $\begin{array}{c}\text { \% of waste } \\
\text { collected }\end{array}$ \\
\hline SWaCH & 2688 & 43 \\
\hline Community Bins & 936 & 40 \\
\hline Tipper Trucks & 160 & 12 \\
\hline Hotel Trucks & 23 & \multirow{2}{*}{} \\
\cline { 1 - 2 } Tractors & 10 & \multirow{2}{*}{5} \\
\cline { 1 - 2 } Dumper Placers & 85 & \\
\hline BRC & 59 & \\
\hline Other & 88 \\
\hline
\end{tabular}

Table 10. Frequency of Collections in Pune

\begin{tabular}{|c|c|c|c|}
\hline $\begin{array}{c}\text { Collection } \\
\text { Mode }\end{array}$ & Organic & $\begin{array}{c}\text { Recyclable / } \\
\text { Non - } \\
\text { Biodegradable }\end{array}$ & $\begin{array}{c}\text { Waste } \\
\text { in } \\
\text { TPD }\end{array}$ \\
\hline $\begin{array}{c}\text { Ghanta } \\
\text { Trucks }\end{array}$ & Daily & Weekly & 350 \\
\hline SWaCH & Daily & - & 865 \\
\hline $\begin{array}{c}\text { Community } \\
\text { Bins and } \\
\text { Containers }\end{array}$ & Daily & - & 150 \\
\hline $\begin{array}{c}\text { Private } \\
\text { collectors }\end{array}$ & Daily & - & 200 \\
\hline
\end{tabular}

\subsubsection{Collection Coverage}

In 2010, P.M.C provided door to door services to $52.70 \%$ of households out of the 524,778 households, which implies that the remaining $47.3 \%$ disposed their waste in community bins. In 2017, this rose to 55\%. Fig. 6 below shows the map of SWaCH services in Pune. In 2016 - 17, SWaCH covered $80.37 \%$ of properties across 41 prabhags in Pune, leaving $19.63 \%$ of households to be serviced and about 100 TPD uncollected. [16, 18, 20, 24, 25]

Table 11. Coverage of Households.

\begin{tabular}{|c|c|c|}
\hline Department & Properties & \% covered \\
\hline SWaCH & 564,421 & 47 \\
\hline Ghantagadi & 316,415 & 27 \\
\hline Private & 71,111 & 6 \\
\hline
\end{tabular}

\subsection{Waste Disposal}

There are currently 7 transfer stations and 50 processing plants which include centralized (7) and decentralized biogas (25), decentralized biodigesters (14), mechanical composting facilities (4) which process $30 \%$ of waste.[20]

$10 \%$ of waste collected is diverted by $\mathrm{SWaCH} .60 \%$ of the remaining is sent to the Urali Devachi landfill, 25 $\mathrm{km}$. away from the city. The landfill site is made up of 43 ha out of which 15 ha is at full capacity and has been permanently sealed off. Waste disposed at the landfill consists of both biodegradable and non-biodegradable matter. It has been estimated that the cost of collection, transportation and disposal of waste is 83.60 crore rupees (or 11.8 million USD) per annum. Unprocessed waste (36\% of total waste) is directly sent to landfill. $[20,26]$

Table 12. Processing Methods in Pune

\begin{tabular}{|c|c|}
\hline $\begin{array}{c}\text { Processing } \\
\text { methods }\end{array}$ & $\begin{array}{c}\text { \% of total waste } \\
\text { processing }\end{array}$ \\
\hline Processed in situ & 7.5 \\
\hline Diverted to farmers & 7 \\
\hline $\begin{array}{c}\text { Diverted to } \\
\text { recycling }\end{array}$ & 10 \\
\hline Sent to landfill & 60 \\
\hline
\end{tabular}

Table 13. Processing Capacity in TPD

\begin{tabular}{|c|c|}
\hline Type & TPD \\
\hline Landfill & 500 \\
\hline Composting plants & 300 \\
\hline Biogas plants & 100 \\
\hline Community & 350 \\
\hline Recycling & 200 \\
\hline
\end{tabular}

The plants are presently operating at $51 \%$ of installed capacity (Fig 6).

\subsection{Successes and Strategies}

The SWM model followed by Pune is commendable in terms of civil society participation through the engagement of informal workers in the form of $\mathrm{SWaCH}$ (Solid Waste Collection and Handling, also translated as "clean"). The cooperative initiative was launched by P.M.C and KKPKP, a union of self-employed waste pickers in 2007. This hybrid model not only empowers the urban poor but has also created a circular economy that has saved an estimated 900 million rupees (12.5 million USD) in labour, transportation and processing costs [27]. $\mathrm{SWaCH}$ diverted $52 \%$ of plastic waste from landfills through recycling, reducing annual greenhouse gas emissions [27].

P.M.C developed a solid waste management strategy plan for 2017 - 2025 [22], which details an action plan that aligns with G25 mission objectives through 4 pathways: the promotion of house-level and society level processing of wet waste, increasing processing efficiency of existing plants by resolving issues, commissioning new plants to meet gaps in processing capacity, and fast tracking the operationalising of commissioned plants. This includes moving towards a $100 \%$ door to door collection (DTDC) system through contracts and civic participation, strengthening existing infrastructure such as vehicles, community bins and route planning by setting a $90 \%$ source segregation target in 2020 - 2025. A noteworthy strategy outlined is the monitoring of operations through an integrated information technology system to track waste streams and provide information on 
indicators which would enable to allocate budgets accordingly. [22, 28]

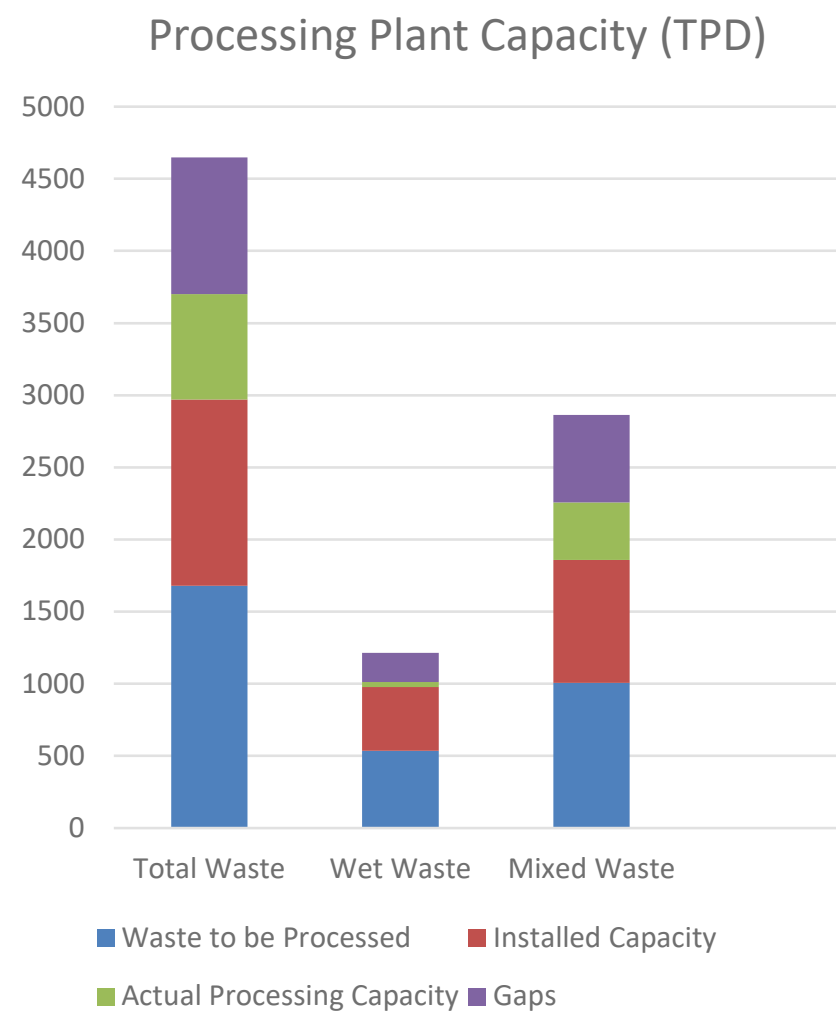

Fig. 6. Processing Plant Capacity (TPD). Source: Solid Waste Management Strategy Plan 2017 - 2025, P.M.C 2017

P.M.C has launched various initiatives such as Clean City Movement, Smart Garbage Management System which implements GPS and tracking technologies to monitor vehicles and to provide information to citizens through apps. Zero Garbage Ward (Katraj Model) which targets reduction in waste sent to landfills, Swachh awards and awareness programs have also been initiated.

Waste to energy models through the bio-conversion process to generate biogas has also been recognized as an important approach to managing waste sustainably, with 25 decentralized biomethanation plants installed and operating and various composting techniques underway [20]. Pune recently installed a plant with capacity 300 MTD capable of generating $11 \mathrm{MW}$ [29]. When waste is processed is locally and decentralized, transportation requirements are reduced and will encourage community engagement. Incineration alternatives in the form of pyrolysis gasification as seen in the Rochem plant which processes 700 TPD has been installed [20]. Additionally, the prevention of leachate leakage through barriers has been adopted. P.M.C has stated that these scientific landfills have been in operation since 2010 [20].

\subsection{Challenges and Opportunities}

With a $50 \%$ segregation success rate, the subsequent chain process of solid waste management undergoes ineffectiveness due to inconsistent categorization of waste according to their properties. This includes physical spaces to facilitate segregation. $\mathrm{SWaCH}$ workers face issues in segregating between plastic types despite advancing plastic recycling in the country. This has resulted in a low-quality categorization between different plastic types for effective recovery and recycling [27]. Recycling options are also limited and a defined integrated system for reuse, recycling and resource recovery is lacking.

Although $\mathrm{SWaCH}$ makes up $43 \%$ of collection services, routines and scheduled times are not always followed and coverage of households and properties needs to be increased. The same issue applies to vehicular collection from secondary sources, which are often unreliable due to breakdowns and unpredictable in terms of timings and route movements [22]. Additionally, while it is important to fund civic infrastructure and services, the fee model may not be viable for the urban poor. P.M.C has also identified a deficiency of adequate staff and skill that lead to coordination between collection and transportation [22].

In terms of policy, P.M.C has faced difficulty in enforcing the SWM byelaws as mandated by the central government of India's Solid Waste Management Rules 2016 [22] as a step towards reducing waste sent to landfill.

Land requirements and acquisition for facilities and processing plants that are situated at an adequate distance from the core urban zone are also issues that would require either alternatives or a shift in prioritizing localized and decentralized methods of processing waste such as community composting.

Technological options that have been implanted such as waste incineration, and other mechanized and centralized processing options pose as threats to the SWM model of Pune due to the vulnerability of their size, financing, upgradation and skill requirements. This has been reflected in processing plants performances in the last few years, as seen in the gaps of processing capacity and actual processed waste.

Though the target to completely stop dumping at landfills within two years has been set and the implementation of scientific landfills has been in operation [22], the use of landfill sites for waste to energy conversion has not been identified. Urali Devachi Landfill for instance has the potential to generate 0.7 MW [30]. The capacity of current landfill infrastructure has been estimated to last only for an additional five years [22]. The gap between landfill operations and information also needs to be reduced by employing monitoring systems to check for failures and pollution levels [30].

As an IT driven economy, the nature of Pune's waste will pose problematic E-Waste generation is predicted to cross over $5000 \mathrm{MT}$ per year. C\&D waste also needs designated disposal methods since it is currently being directly disposed in low lying areas along rivers [20].

\section{Discussion}

While Pune belongs to a country that has a very low GDP per capita as compared to Sydney's, we see that some 
defining strategies are successful. This is particularly true in the case of the SWaCH workers. However, this model has grounds of comparison in Sydney, in that it has also been implemented on a larger scale through the contracting of private business owners and privatization of waste management infrastructure. In one case, the model is successful because it is based on the community level, whereas in the second, the model is also successful because of individual business agents, and the sector is contributing significantly to the country's GDP. It is important to remember, however, that because $\mathrm{SWaCH}$ workers belong to the informal sector, this model has larger potential in economies of scale as well as of scope, provided that the system set in place could be more streamlined and organized to increase efficiency in terms of timings and frequency. Furthermore, the framework in which this sector operates has raised awareness in inclusivity and has paved the way for a transformation in traditional modes of operation in India.

Secondly, the collection of waste is the most crucial aspect of solid waste management. Whether this is done by private or public agents, waste collection will reduce unsanitary conditions, reduce greenhouse gas emissions, prevent open dumping in public spaces, and reduce the chances of discarding waste in ecologically sensitive areas. In Sydney, the collection of domestic waste has been implemented systematically with $100 \%$ collection coverage. And although the collection of commercial and industrial as well as C\&D waste is left to licensed contractors, it is observed that the City has maintained its eye on operations through tracking and monitoring systems. Pune's collection coverage can be improved. However, it is understandable that lower income groups may not have the capacity to be charged a fee, and the structural composition of the city is such that it may be somewhat difficult in collecting from all corners. As the cooperative increases in size, the collection coverage will also increase.

In terms of waste disposal and processing, it is important to learn from Sydney's City Council in how the dissemination of policies have led to an improvement in community recycling initiatives and sensitivity of waste management in city dwellers. Having several decentralized waste processing techniques could allow access to appropriate solid waste management even for corner areas of the city. This could range from community composting to materials recovery and larger waste processing infrastructure.

Following the initiative of $\mathrm{SWaCH}$, a low-income country could join the challenge for a more sustainable future in not only how waste is collected, but also how it is recycled and processed through $\mathrm{SWaCH}$ handling of waste directly. Both high and low GDP per capita countries could also invest in alternative waste treatments and waste to energy models that could assist in the development of renewable energy. This has been observed in both cities.

\section{References}

1. L.Yao, S. Kaza, P. Bhada-Tata, F.V. Woerden, What a Waste 2.0: A Global Snapshot of Solid Waste Management to 2050 (2018)

2. UN-Habitat, SDG Indicator 11.16.1 Training Module: Solid Waste Management in Cities. (United Nations Human Settlement Programme, Nairobi, 2018)

3. UNDP, Human Development Indices and Indicators: 2018 Statistical Update. (United Nations, New York, 2018)

4. City of Sydney, Leave Nothing to Waste. Strategy and Action Plan 2017 - 2030 (2017)

5. City of Sydney, Environment Action 2016 - 2021. Strategy and Action Plan (2017)

6. City of Sydney, Governance Guide (2014)

7. City of Sydney, Waste Policy, Sydney 2030 (2017)

8. J. Pickin, P. Randell, J. Trinh, B. Grant, National Waste Report 2018 (2018)

9. R. Wainberg, J. Pickin, Australian landfill capacities into the future (2009)

10. City of Sydney, Advanced Waste Treatment Master Plan 2013 - 2030 (2014)

11. Department of Environment, Climate Change and Water NSW, Review of Waste Strategy and Policy in New South Wales (Government of Australia, 2010)

12. C.o.S, Green Environmental Sustainability Progress Report (2019)

13. NSW EPA, Waste Levy (2019)

14. NSW EPA, Waste Less, Recycle More (2019)

15. C. Harvey, Dial a dump: Sydney's $\$ 300 m$ hole will become the biggest rubbish dump in the southern hemisphere (Daily Telegraph, 2011)

16. P.Chikarmane, L. Narayan, Solid Waste Generation and Collection in Pune (2006)

17. Office of the Registrar General \& Census Commissioner, Census 2011 (Government of India, 2011)

18. P.M.C, Pune City Sanitation Plan (2012)

19. P.M.C, Public-Health \& Sanitation Bye-laws (2014)

20. P.M.C, Integrated Solid Waste Management (2016)

21. P. Chikarmane, Integrating Waste Pickers into Municipal Solid Waste Management in Pune, India (2012)

22. P.M.C, Solid Waste Management Strategy Plan 2017 - 2025 (2017)

23. P.M.C, Revising/Updating the City Development Plan of Pune City - 2041 (2012)

24. P.M.C, Total quantity of waste collected for 2017 (2017)

25. P.M.C, Property wise waste collected by the solid waste department for the year 2017 (2017)

26. M.T.T, H.H.N, Existing Situation of Solid Waste Management in Pune City, India, Res. J. Recent Sci, 1, 348 (2012)

27. H. Moora, H. Barde, Closing the Loop: Pune, India Case Study (2017) 
28. P.M.C, Pune Towards Smart City (2015)

29. Central Pollution Board, Consolidated Annual Report for the year 2016-2017 (Government of India, 2017)

30. T. Paul, N. Soren, An overview of municipal solid waste-to-energy application in Indian scenario, Environ. Dev. Sustain. 22, 575 (2018) 